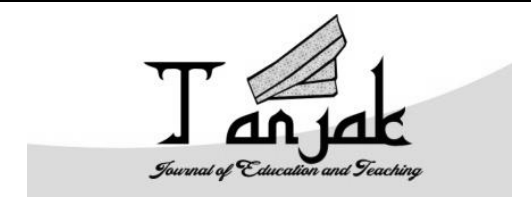

\author{
Tanjak: Journal of Education and Teaching \\ ISSN 2716-4098 (P) 2720-8966 (O) \\ Volume 1 Nomor 2, 2020
}

\title{
HUBUNGAN DUKUNGAN SOSIAL TERHADAP MOTIVASI BELAJAR DARING MAHASISWA PADA MASA PANDEMI COVID-19
}

\author{
Nadya Nela Rosa ${ }^{1 *}$ \\ ${ }^{1}$ STAIN Sultan Abdurrahman, Toapaya Asri Kabupaten Bintan, Kepulauan Riau, 29132, Indonesia
}

DOI: https://doi.org/10.35961/tanjak.v1i2.146

\begin{abstract}
Abstrak
Penelitian ini bertujuan untuk melihat hubungan dukungan sosial terhadap motivasi belajar daring mahasiswa pada masa pandemi covid-19. Penelitian ini menggunakan metode kuantitatif dengan teknik pengambilan sampel ialah teknik cluster sampling. Instrumen yang digunakan adalah skala dukungan sosial dan skala motivasi belajar yang disebarkan menggunakan media google form. Teknik analisis data yang digunakan adalah analisis regresi linier. Hasil analisis data menunjukkan $\mathrm{R}=$ 0.527 dan tingkat signifikansi ( $p$ ) 0,000 ( $<<0,01$ ). Berdasarkan hasil penelitian dan pembahasan, dapat dilihat bahwa terdapat pengaruh hubungan yang sangat signifikan antara dukungan sosial terhadap motivasi belajar.
\end{abstract}

Kata kunci: Dukungan sosial; motivasi belajar daring mahasiswa; pandemi covid-19

\begin{abstract}
This study aims to determine the relationship of social support to student's online learning motivation during the pandemic covid-19. This research used quantitative methods with the sampling technique used in this research is cluster sampling. The instrument was used a scale of social support and learning motivation scale distributed using google form media. The data analysis technique used is linear regression analysis. The results of data analysis showed $\mathrm{R}=0.527$ and a significance level ( $p$ ) of $0.000(p<0.01)$. Based on the results of research and discussion, it can be seen that there is a very significant relationship between social support and learning motivation.
\end{abstract}

Keywords: social support; motivation to learn; pandemic covid-19

Tanjak: Jounal of Education and Teaching, Vol. 1, No. 2, 2020 


\section{Pendahuluan}

Perkuliahan tatap muka selama wabah corona virus disease 2019 (covid-19) dialihkan menjadi perkuliahan dan pembelajaran secara daring (Surat edaran Kemendikbud Dikti No.1 tahun 2020). Pembelajaran secara daring atau online ini ditujukan untuk memutus mata rantai penyebaran covid-19 yang telah melanda 215 negara di dunia. Pemerintah mengambil kebijakan dan melarang agar masyarakat tidak berkumpul, menjaga jarak (physical distancing), pembatasan sosial (social distancing), memakai masker, selalu mencuci tangan dan menaati protokol kesehatan yang telah dianjurkan pemerintah (Firman dan Rahman, 2020).

Pemerintah mengantisipasi penyebaran virus covid-19 melalui surat edaran yang dikeluarkan, terdapat 10 poin salah satunya adalah anjuran untuk melaksanakan kegiatan pembelajaran secara daring atau online. Pembelajaran daring atau online memiliki kelebihan dan hambatan dalam implementasinya. Beberapa perguruan tinggi di Indonesia dengan cepat melaksanakan intruksi yang telah dikeluarkan untuk dapat diterapkan di institusi pendidikan (Yandwiputra, 2020). Tidak terkecuali di lingkungan kampus STAIN Sultan Abdurrahman Kepulauan Riau (STAIN SAR KEPRI) dengan segera mengeluarkan surat intruksi agar perkuliahan diadakan secara daring guna pencegahan dan memutus rantai penyebaran corona virus disease (Covid-19).

Pencegahan penyebaran covid-19 dapat dilakukan dengan cara menghentikan acara atau kegiatan yang menyebabkan masa berkumpul. Pembelajaran yang dilakukan secara tatap muka perlu ditinjau ulang pelaksanaannya karena mengumpulkan banyak mahasiswa di dalam satu ruang. Upaya pencegahan penularan dapat dilakukan dengan cara meniadakan perkuliahan secara tatap muka yang berhubungan secara fisik antara mahasiswa dengan mahasiswa lainnya ataupun dosen dengan mahasiswa sehingga dapat meminimalisir penyebaran virus ini (Firman dan Rahman, 2020). Penggunaan teknologi digital menjadi alternatif dalam melaksanakan pembelajaran meskipun dosen dan mahasiswa berada ditempat yang berbeda (Milman, 2015).

Tempat dan waktu tidak menjadi kendala bagi mahasiswa untuk dapat mengikuti perkuliahan secara daring, dosen dapat memberikan materi perkuliahan melalui kelas-kelas virtual yang dapat di akses mahasiswa dan mahasiswa dapat mengikuti perkuliahan dari rumah masing-masing Perkuliahan yang dilaksanakan mahasiswa di rumah membuat mahasiswa dapat secara bebas memilih mata kuliah yang diikuti dan tugas-tugas perkuliahan mana yang harus dikerjakan terlebih dahulu (Sadikin dan Hamidah, 2020). Laursen (Rozali, 2013) menyatakan bahwa tantangan dalam menyelesaikan tugas-tugas perkuliahan ini akan sangat terbantu oleh kelompok teman sebaya yang positif yang akan sangat membantu mahasiswa dalam memahami bahwa ia tidak sendiri dalam menyelesaikan tugas perkuliahannya. Kelompok teman sebaya ini merupakan salah satu sumber dukungan sosial, selain itu pasangan, keluarga, rekan kerja, dosen dan anggota organisasi juga merupakan sumber dukungan sosial (Suciani dan Rozali, 2014).

Dukungan sosial menurut Cohen dan Syme (Apollo dan Cahyadi, 2012) adalah sumber-sumber yang didapati individu dari orang lain yang dapat mempengaruhi kesejahteraan individu yang bersangkutan. Dukungan sosial menurut House dan Khan (Apollo dan Cahyadi, 2012) yaitu tindakan membantu yang melibatkan pemberian informasi, bantuan instrumen, emosi dan penilaian postitif terhadap individu dalam menghadapi permasalahnnya. Menurut Cohen dan Hoberman (Isnawati dan Suhariadi, 2013) dukungan sosial adalah hubungan antar pribadi seseorang dengan orang lain yang mengacu pada sumber daya yang disediakan antar keduanya. Menurut Zimet, Dahlem, Zimet dan Farley 
(1988), aspek dukungan sosial terdiri dari dukungan yang diberikan keluarga, dukungan yang diberikan teman dan dukungan dari orang terdekat.

Dari hasil wawancara yang dilakukan peneliti kepada beberapa mahasiswa diketahui bahwa mahasiswa termotivasi untuk mengikuti perkuliahan secara daring karena perhatian dan dukungan dari orangtua untuk memenuhi kuota internet yang digunakan untuk mengakses perkuliahan daring. Mahasiswa lain mengungkapkan bahwa ia memperoleh dukungan dan semangat dari teman-temannya, mereka dapat berdiskusi mengenai tugas dan saling mengingatkan tugas dan jadwal perkuliahan online sehingga mahasiswa tersebut memperoleh dukungan yang positif dan merasa tidak sendiri dalam mengerjakan tugas perkuliahan. Lalu ada juga mahasiswa yang tidak memperoleh dukungan sosial dari orangtua dan teman-temannya, seperti tidak diberikan dukungan untuk memenuhi kuota internet dan teman-teman yang berperilaku sedikit acuh. Berdasarkan hasil wawancara didapatkan hasil bahwa mahasiswa yang mendapatkan dukungan sosial yang cukup dan positif cenderung motivasi belajarnya meningkat, sedangkan yang kurang mendapatkan dukungan sosial menunjukkan motivasi belajar yang rendah seperti malas mengikuti perkuliahan daring dengan dalih kuota untuk mengakses internet tidak ada. Hasil temuan wawancara yang peneliti lakukan sejalan dengan penelitian yang telah dilakukan oleh Dhitaningrum dan Izzati (2013) didapati bahwa siswa yang memiliki persepsi terhadap dukungan sosial keluarganya akan memiliki motivasi belajar yang tinggi.

Motivasi belajar menurut Clayton (Hamdu dan Agustina, 2011) adalah hasrat yang mendorong siswa untuk mencapai hasil belajar sebaik mungkin dalam kegiatan belajar. Motivasi belajar menurut Uno (2016) terdiri dari dua faktor, yaitu faktor intrinsik dan faktor ekstrinsik. Faktor instrinsik berupa Hasrat dan keinginan untuk berhasil, dorongan kebutuhan belajar, kegiatan belajar yang menarik dan lingkungan belajar yang kondusif. Sedangkan faktor ekstrinsik berupa penghargaan, kegiatan belajar yang menarik dan lingkungan belajar yang kondusif.

Menurut Winkel (2014) motivasi belajar merupakan penggerak dalam psikis diri siswa yang menimbulkan kegiatan belajar, memberikan arah pada kegiatan belajar, serta menjamin keberlangsungan kegaiatan belajar demi mencapai suatu tujuan. VanBreda (2015) mengatakan bahwa siswa yang membolos dan motivasi belajarnya rendah pada umumnya memiliki orangtua dengan tingkat keterlibatan dan dukungan sosial yang buruk dan tidak konsisten. Keterlibatan orangtua berpengaruh terhadap terpenuhinya kebutuhan anak akan dukungan sosial. Hasil penelitian Dhitaningrum dan Izzati (2013) mengatakan bahwa motivasi belajar yang rendah disebabkan karena kurang mendapatkan dukungan sosial yang diberikan orangtua.

Motivasi belajar merupakan salah satu faktor untuk keberhasilan dalam pembelajaran daring, sehingga perlu mempertimbangkan motivasi belajar di lingkungan belajar yang memanfaatkan teknologi (Harandi, 2015). Aspek motivasi belajar yang dipaparkan oleh Uno (2016) mengatakan bahwa ada 6 indikator motivasi belajar yaitu hasrat keinginan untuk berhasil, harapan cita-cita kedepan, penghargaan dalam belajar, keinginan yang menarik dalam belajar, lingkungan yang kondusif sehingga memungkinkan seseorang dapat belajar dengan baik dan kebutuhan dalam belajar atau dorongan.

\section{Metode Penelitian}

Rancangan penelitian yang digunakan dalam penelitian ini menggunakan pendekatan kuantitatif dengan teknik cluster sampling, menurut Sugiyono (2017) cluster sampling adalah teknik untuk menentukan sampel apabila obyek atau sumber data penelitian yang akan diteliti sangat luas, maka 
pengambilan sampel berdasarkan daerah populasi yang telah ditetapkan, teknik ini mengambil 2 dari 3 kelas populasi untuk dijadikan penelitian.

Jumlah populasi dalam penelitian ini adalah sebanyak 100 mahasiswa aktif prodi manajemen pendidikan islam, prodi pendidikan anak usia dini dan prodi hukum keluarga islam. Jumlah sampel dalam penelitian ini adalah 87 mahasiswa. Dalam menentukan jumlah sampel yang akan digunakan peneliti menggunakan tabel Isaac dan Michael untuk tingkat kesalahan 1\%.

Teknik pengumpulan data pada penelitian ini menggunakan kuesioner skala likert yang disebarkan menggunakan media google form. Pengembangan instrumen penelitian untuk variabel dukungan sosial menggunakan skala Multidimensional Scale of Perceived Social Support (MSPSS) yang berisi 12 aitem yang dikembangkan oleh Zimet, Dahlem, Zimet dan Farley (1988), dukungan sosial meliputi dukungan dari keluarga (family support), dukungan dari teman (friend support) dan dukungan dari orang terdekat (significant others support), untuk variabel motivasi belajar menggunakan skala motivasi belajar mahasiswa yang diadaptasi dan dikembangkan dari indikator motivasi belajar menurut Uno (2016).

Teknik analisis data yang digunakan pada penelitian ini adalah pearson's product moment correlation dan menggunakan program Statistical Packages for Social Science (SPSS) version 23 for Windows. untuk menemukan hubungan antara dukungan sosial terhadap motivasi belajar daring mahasiswa yang sebelumnya telah dilakukan uji normalitas dan uji linieritas.

\section{Hasil dan Pembahasan}

Hasil analisis menunjukkan adanya hubungan yang sangat signifikan antara dukungan sosial terhadap motivasi belajar daring mahasiswa STAIN Sultan Abdurrahman Kepulauan Riau. Berdasarkan deskriptif data maka subjek dikategorikan ke dalam dua kategori yaitu tinggi dan sedang. Hipotesis penelitian ini semakin tinggi nilai dukungan sosial maka semakin tinggi pula motivasi belajar daring mahasiswa. Kategorisasi subjek menunjukkan bahwa sebagian besar subjek penelitian memiliki dukungan sosial sebanyak 76 mahasiswa $(87,4 \%)$ berada pada kategori sedang. Hal ini menunjukkan bahwa sebagian besar subjek penelitian memiliki dukungan sosial yang cukup. Sedangkan motivasi belajar daring mahasiswa termasuk dalam kategori tinggi sebanyak 69 mahasiswa (79,3\%) sehingga dapat disimpulkan bahwa motivasi belajar daring yang diperoleh subjek cukup.

Hasil penelitian menunjukkan adanya hubungan yang sangat signifikan antara dukungan sosial terhadap motivasi belajar daring mahasiswa. Hasil penelitian diatas sejalan dengan penelitian yang dilakukan oleh Tentama, Subardjo dan Abdillah (2019) yang berjudul Motivation to Learn and Social Support Determine Employability among Vocational High School Students. Penelitian tersebut mendapatkan hasil bahwa motivasi untuk belajar dan dukungan sosial memiliki pengaruh terhadap kinerja siswa.

Hasil penelitian ini sejalan dengan penelitian Tezci, Sezer, Gurgan dan Aktan (2017) yang berjudul A Study on Social Support and Motivation. Penelitian tersebut mendapatkan hasil bahwa ada korelasi positif antara dukungan sosial terhadap motivasi eksternal dan internal siswa, subjek yang menerima dukungan sosial yang memadai akan meningkatkan motivasi eksternal dan internal.

Sumbangan efektif yang didapat dari hasil penelitian menunjukkan variabel dukungan sosial dan variabel motivasi belajar memberikan sumbangan efektif sebesar 52,7\% dengan hasil $\mathrm{R}$ square sebesar 0,527. Hal ini menunjukkan bahwa adanya faktor lain diluar lingkup penelitian ini sebesar 47,3\% yang dapat mempengaruhi motivasi belajar. Hal ini sejalan dengan hasil penelitian Dhitaningrum dan 
Izzati (2013) yang berjudul hubungan antara persepsi mengenai dukungan sosial orangtua dengan motivasi belajar siswa yang mendapatkan hasil bahwa siswa yang tidak mendapatkan dukungan sosial dari orang lain maka keinginannya untuk belajar akan menurun, bermalas-malasan dalam mengerjakan tugas, keinginan belajar menurun tidak semangat dan berjuang sendiri dalam mengerjakan tugas yang diberikan sehingga ketika perkuliahan sedang berlangsung maka subjek menjadi tidak bergairah untuk mengikuti perkuliahan.

\section{Uji Korelasi Pearson's Product Moment}

Besaran korelasi antara variabel sebesar 0,527 atau sebesar 52,7\% dan bernilai positif, dengan demikian dapat disimpulkan bahwa semakin besar dukungan sosial maka semakin besar juga motivasi belajar daring mahasiswa.

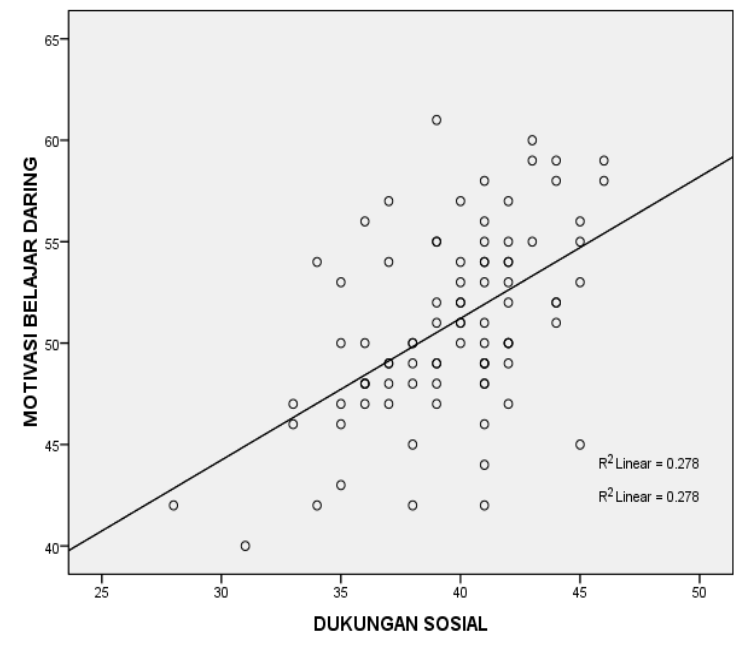

Gambar 1. Output Uji Korelasi Pearson's Product Moment

Implikasi dari penelitian ini dapat memberikan wawasan dan kesadaran kepada orangtua, teman dan orang terdekat mahasiswa akan pentingnya dukungan sosial terhadap motivasi belajar daring mahasiswa. Penelitian ini menunjukkan bahwa dukungan sosial internal maupun eksternal yang didapatkan dari orangtua, teman sejawat dan orang terdekat memiliki peran dalam meningkatkan motivasi belajar daring mahasiswa di masa pandemi covid-19 ini. Orangtua, teman-teman sejawat dan orang terdekat mahasiswa harus mampu unuk menciptakan lingkungan yang positif sehingga mereka dapat memberikan motivasi dan dukungan sosial bagi mahasiswa. Dengan demikian mahasiswa akan lebih siap untuk bersaing dan mengerjakan tugas sehingga target nilai yang diinginkan tercapai.

\section{Kesimpulan}

Salah satu faktor yang mempengaruhi motivasi belajar daring mahasiswa pada masa pandemi covid-19 adalah dukungan sosial. Penelitian ini mendapatkan hasil bahwa ada pengaruh yang signifikan antara dukungan sosial dengan motivasi belajar daring mahasiswa di STAIN Sultan Abdurrahman 
Kepri. Sebanyak 76 mahasiswa memiliki dukungan sosial pada kategori sedang dan sisanya sebanyak 11 mahasiswa berada pada kategori dukungan sosial yang tinggi dan sebanyak 18 mahasiswa memiliki dukungan sosial pada kategori sedang dan sisanya sebanyak 69 mahasiswa berada pada kategori dukungan sosial yang tinggi.

\section{Ucapan Terimakasih}

Penulis mengucapkan terimakasih kepada mahasiswa-mahasiswa prodi manajemen pendidikan islam, prodi pendidikan anak usia dini dan prodi hukum keluarga islam STAIN Sultan Abdurrahman Kepri untuk bantuan teknis dalam penelitian ini. Penulis juga berterima kasih kepada semua yang berpartisipasi dalam keterlibatan pada penelitian ini.

\section{Referensi (APA $6^{\text {th }}$ Style, Mendeley dsj)}

Apollo., \& Cahyadi, A. (2012). Konflik peran ganda perempuan menikah yang bekerja ditinjau dari dukungan sosial keluarga dan penyesuaian diri. Jurnal widya warta, 02(01), 255-271.

Dhitaningrum, M., \& Izzati, U. A. (2013) Hubungan antara persepsi mengenai dukungan sosial orang tua dengan motivasi belajar siswa. Jurnal psikologi universitas negeri surabaya, 1(1), 1-6.

Firman., \& Rahman, S. R. (2020). Pembelajaran online di tengah pandemi covid-19. Indonesian journal of educational science (ijes), 02(02), 81-80.

Hamdu, G., \& Agustina, L. (2011). Pengaruh motivasi belajar siswa terhadap prestasi belajar ipa di sekolah dasar. Jurnal penelitian Pendidikan, 11(01). 80-88.

Harandi, S R. (2015). Effect of e-learning on students' motivation. Procedia-social and behavioral science, 181(01). 423-430.

Isnawati, D., \& Suhariadi, Fendy. (2013). Hubungan antara dukungan sosial dengan penyesuaian diri masa persiapan pensiun pada karyawan pt pupuk kaltim. Jurnal psikologi industri dan organisasi, 02(01), 1-6.

Milman, N. B. (2015). The flipped classroom strategy: What is it and how can it best be used?. Distance Learning, 9(3), 85-87.

Rozali, Y. A. (2013). Pengaruh Peer Counselling Terhadap Peningkatan Self Regulation Pada Mahasiswa Skripsi Universitas X. (Unpublished master's thesis).

Sadikin, A., \& Hamidah, A. (2020). Pembelajaran Daring di Tengah Wabah Covid-19. Biodik, 6(2), 214224. https://doi.org/10.22437/bio.v6i2.9759

Suciani, D., \& Rozali, Y. A. (2014). Hubungan dukungan sosial dengan motivasi belajar mahasiswa universitas esa unggul. Jurnal psikologi. 12(02), 1-5. 
Sugiyono. (2017). Metode penelitian. Bandung: IKAPI (Anggota Ikatan Penerbit Indonesia).

Tentama, F., Subardjo., \& Abdillah, M. H. (2019). Motivation to learn and social support determine employability among vocational high school students. International Journal of Evaluation and Research in Education (IJERE). 8(02), 237-242.

Tezci, E., Sezer, F., Gurgan, U., \& Aktan, S. (2015). A study on social support and motivation. Journal The anthropologist. 22(02), 284-292.

Uno, H. B. (2016). Teori motivasi dan pengukurannya analisis di bidang pendidikan. Jakarta: Bumi Aksara.

Winkel, W. S. (2014). Psikologi pengajaran. Jakarta: Grasindo.

Yandwiputra, A. R. (2020). Kuliah Jarak Jauh karena Virus Corona, UI: Bukan Lockdown. dalam Metro Tempo.co. Retrieved from https://metro.tempo.co/read/1319537/kuliah-jarak-jauh-karenaviruscorona-ui-bukan-lockdown.

Zimet, G., Dahlem, N. W., Zimet, S. G. dan Farley, G. K. (1988). The multidimensional scale of perceived social support. Journal of personality assessment. 52(1), 30-41. doi: 10.1207/s15327752jpa5201_2 